\title{
Study on the Determination of Trace Lead and Cadmium by ICP-MS After Preconcentration and Separation on Carbon Nanofibers Loaded With 8-Hydroxyquinoline
}

\author{
Juntao Yan, Shizhong Chen`, Jianfen Li, Yuayuan He, and Dengbo Lu \\ College of Chemical and Environmental Engineering, \\ Wuhan Polytechnic University, Wuhan 430023, P.R. China
}

\section{INTRODUCTION}

It is well known that lead $(\mathrm{Pb})$ and cadmium (Cd) are ubiquitous elements in the environment and extensively used in various industrial fields of electroplating, metal finishing, metallurgical production, batteries, and semiconductors. In addition, the non-biodegradable nature of $\mathrm{Pb}$ and $\mathrm{Cd}$ makes them a major worldwide problem (1-3). $\mathrm{Pb}$ can affect almost all organs and systems in the human body, resulting in blood enzyme, hyperactivity, and neurological disorders $(4,5)$. As a non-essential heavy metal, Cd does not have any functions in the human metabolism but causes damage to organs such as kidneys, liver, and lungs $(6,7)$. Therefore, a sensitive, reproducible, and accurate analytical method is required for the determination of trace/ultratrace $\mathrm{Pb}$ and $\mathrm{Cd}$ in environmental and biological samples.

Inductively coupled plasma mass spectrometry (ICP-MS) has been accepted as the most powerful and sophisticated atomic spectrometric technique owing to its high sensitivity, low detection limit, wide linear dynamic range, and rapid multielemental analysis capability (8-12). Sometimes, however, direct analysis of environmental and biological samples by ICP-MS is still a difficult task, not only because the concentrations levels of trace elements are quite low, but also because a complicated matrix often interferes with their determination (13). Thus, the enrichment/ separation of analytes from matri-

*Corresponding author.

E-mail: chenshizhong62@163.com

Tel: +862783956442

\section{ABSTRACT}

A novel method was developed for the preconcentration, separation, and determination of trace lead $(\mathrm{Pb})$ and cadmium (Cd) by inductively coupled plasma mass spectrometry (ICPMS), based on carbon nanofibers (CNFs) loaded with 8-Hydroxyquinoline (HOx) as a solid phase extraction adsorbent. The adsorption behaviors of the analytes on CNFs-HOx were investigated. The effects of $\mathrm{pH}$, sample flow rate and volume, elution solution and interfering ions on the preconcentration and separation of the analytes were examined in detail. The adsorption capacity of CNFs-HOx for $\mathrm{Pb}$ and Cd was $4.3 \mathrm{mg} \mathrm{g}^{-1}$ and $5.0 \mathrm{mg} \mathrm{g}^{-1}$, respectively. Under the optimum conditions, the detection limits of $\mathrm{Pb}$ and $\mathrm{Cd}$ were 3.0 and 0.7 pg $\mathrm{mL}^{-1}$ with an enrichment factor of 100-fold, respectively, while the relative standard deviations (RSDs) were less than 5.0\% for both elements $\left(\mathrm{c}=1.0 \mathrm{ng} \mathrm{mL}{ }^{-1}\right.$ $\mathrm{n}=9$ ). This method was applied to the determination of trace $\mathrm{Pb}$ and $\mathrm{Cd}$ in environmental and biological samples with recoveries of $95-103 \%$. In order to validate this method, a certified reference material of mussel (GBW 08571) was analyzed, and the determined values are in good agreement with the certified values.

ces has become an essential part of spectrometric analysis, including solvent extraction $(14,15)$, coprecipitation $(16,17)$, solid phase extraction (SPE) $(18,19)$, liquid phase microextraction $(20,21)$, and chromatography $(22,23)$ which have been commonly used for sample pretreatment. Among them, SPE has received increasing attention in the separation/preconcentration of trace elements and elimination of matrix interference due to its high concentration factor, simple operation, rapid phase separation, and in combination with different analytical techniques. Being a most key factor of separation and preconcentration, the sorbent material used for SPE determines the sensitivity and selectivity of the analytical method.

In recent years, nanometer-size materials have drawn growing attention in the analytical sciences because of their special properties (24-30). As a novel and interesting material, carbon nanofibers (CNFs) have been used for hydrogen storage and the separation/preconcentration of trace elements due to their high chemical stability and large specific surface area (31-34). It is worth noting that some investigations showed that an important strategy for elemental enrichment/ separation is the incorporation of complexing reagents in nanometer solid supports (35-39). To the best of our knowledge, however, studies on the separation and preconcentration of trace elements have received little attention using $\mathrm{CNFs}$ loaded with 8-Hydroxyquinoline (HOx) as a solid phase extraction adsorbent. The present work is aimed at evaluating the adsorptive potential of CNFs loaded with $\mathrm{OHx}$ for trace $\mathrm{Pb}$ and $\mathrm{Cd}$. On the basis of the experimental results obtained, a novel method was developed for the separation and preconcentration of trace $\mathrm{Pb}$ and $\mathrm{Cd}$ by a microcolumn packed with CNFs loaded with HOx before ICP-MS determination. This method validation was performed and applied for the 
determination of trace $\mathrm{Pb}$ and $\mathrm{Cd}$ in environmental and biological samples.

\section{EXPERIMENTAL}

\section{Instrumentation}

A Thermo Elemental X-7 ICP-MS (Thermo Elemental Corporation, USA), equipped with a standard low-volume glass impact bead spray chamber, a concentric glass nebulizer and Fassel-type torch, was used in this work. The samples and standards were spiked with $2.0 \mathrm{ng}$ $\mathrm{mL}^{-1}$ of indium internal standard before measurement. The ion lens settings, nebulizer flow rate, and torch position of the instrument were optimized daily to obtain the maximum ${ }^{115}$ In count rate. The operating parameters for ICP-MS are listed in Table I.

A Model HL-2 peristaltic pump (Shanghai Qingpu Huxi Instrument Factory, P.R. China), coupled to a self-made polytetrafluoroethylene (PTFE) microcolumn $(20 \mathrm{~mm} \times 3.0$ $\mathrm{mm}$ i.d.), packed with CNFs-OHx, was used for the preconcentration and separation process. A minimum length of PTFE tubing with an i.d. of $0.5 \mathrm{~mm}$ was used for all connections. The $\mathrm{pH}$ values of the solutions were controlled with a $\mathrm{pH}$ meter (Thermo Orion Corporation, USA), supplied with a combined electrode. A Model Ethos T microwave system (Milestone, Italy) was used for sample digestion.

\section{Standard Solution and Reagents}

Standard solutions of $\mathrm{Pb}$ and $\mathrm{Cd}$ (1.0 $\mathrm{mg} \mathrm{mL}^{-1}$ ) were prepared by diluting the stock standard solutions available from the National Analysis Center of Iron \& Steel (Beijing, P.R. China). All reagents used were ultrapure or at least of analytical grade. High purity water obtained from a Milli-Q ${ }^{\circledR}$ A10 system (Millipore Corporation, USA) was used throughout this work. The OHx solution was prepared by dissolving proper amounts of $\mathrm{OHx}$
(Shanghai Reagent Factory, P.R. China) in ethanol- $\mathrm{H}_{2} \mathrm{O}(\mathrm{v} / \mathrm{v}, 1: 4)$.

The CNFs were kindly provided by Shenyang Metal Institute of Chinese Academy (Shenyang, P.R. China). Before use, the CNFs were oxidized with concentrated $\mathrm{HNO}_{3}$ according to the literature (40). The treated CNFs were dried at $100{ }^{\circ} \mathrm{C}$ and stored for future use.

\section{Column Preparation with OHx}

Twenty milligrams of the treated CNFs was introduced into a PTFE microcolumn $(20 \mathrm{~mm} \times 3.0 \mathrm{~mm}$ i.d.) plugged with a small portion of glass wool at both ends using the conventional method. Before use, $1.0 \mathrm{~mol} \mathrm{~L}^{-1} \mathrm{HNO}_{3}$ solution and high purity water were passed through the column to clean it. Then, the column was washed with high purity water to $\mathrm{pH} 7$. Finally, $1.0 \times 10^{-4} \mathrm{~mol} \mathrm{~L}^{-1} \mathrm{OHx}$ solution was passed through the column at a flow rate of $0.2 \mathrm{~mL} \mathrm{~min}^{-1}$ for $5 \mathrm{~min}$ utes. The filtrate was collected and analyzed for non-adsorbed $\mathrm{OHx}$ by UV-Vis spectrophotometry at 304 $\mathrm{nm}$. The retained amount of $\mathrm{OHx}$ on the CNFs was $7.9 \mathrm{mg} \mathrm{g}^{-1}$ according to the calculation.

\section{Sample Pretreatment}

A sample portion $(0.8000 \mathrm{~g}$ of mussel) was accurately weighed into 100-mL Teflon ${ }^{\circledR}$ vessels, and

\section{Atomic Apectroscopy $\bigcup$ Vol. 38(2), Mar./Apr. 2017}

then $8.0 \mathrm{~mL}$ concentrated $\mathrm{HNO}_{3}$ and $2.0 \mathrm{~mL}$ of $35 \% \mathrm{H}_{2} \mathrm{O}_{2}(\mathrm{~m} / \mathrm{V})$ were added, respectively. After about 5 minutes, when the first vigorous reaction had taken place, the digestion vessels were closed and placed into the microwave oven. The samples were digested in the microwave oven at $180{ }^{\circ} \mathrm{C}$ (ramp, 15 minutes; hold, 30 minutes) at the power of $1.0 \mathrm{~kW}$. When the digestion programs were completed, the vessels were cooled to room temperature. The vessels were then opened carefully, and a clear acid phase was observed. The clear acid phase from the microwave digestion was transferred to another vessel and then heated on the hotplate at $140{ }^{\circ} \mathrm{C}$ to evaporate excess reagents. After reaching near dryness, the residues were dissolved with $0.1 \mathrm{~mol} \mathrm{~L}^{-1} \mathrm{HNO}_{3}$ and diluted to a desired volume.

A natural water sample, collected from Dongxi Lake (Wuhan, P.R. China), was filtered through a $0.45 \mu \mathrm{m}$ membrane filter and analyzed as soon as possible after sampling. Procedural blanks were prepared in the same way.

\section{Procedure}

Sample solutions were prepared by appropriate dilution of the stock solutions and adjusted to the desired $\mathrm{pH}$ with the mixture solu-

TABLE I

Operating Parameters for ICP-MS

\begin{tabular}{ll} 
Plasma Power & $1.3 \mathrm{~kW}$ \\
Plasma Argon Flow Rate & $14.5 \mathrm{~L} \mathrm{~min}^{-1}$ \\
Auxiliary Argon Flow Rate & $0.75 \mathrm{~L} \mathrm{~min}^{-1}$ \\
Nebulizer Argon Flow Rate & $0.96 \mathrm{~L} \mathrm{~min}$ \\
Sampler Orifice (nickel) & $1.1 \mathrm{~mm}$ \\
Skimmer Orifice (nickel) & $0.7 \mathrm{~mm}$ \\
Acquisition Mode & Peak-jumping \\
Number of Sweep & 100 \\
Dwell Time & $10 \mathrm{~ms}$ \\
Acquisition Time & $40 \mathrm{~s}$ \\
Number of Measurements per Peak & 3 \\
Isotopes & ${ }^{208} \mathrm{~Pb},{ }^{111} \mathrm{Cd}$ and ${ }^{115} \mathrm{In}$ \\
\hline
\end{tabular}


tion of $\mathrm{NH}_{3} \cdot \mathrm{H}_{2} \mathrm{O}$ and $\mathrm{NH}_{4} \mathrm{Cl}$. The obtained solution was passed through the microcolumn with a peristaltic pump at a desired flow rate. Afterwards, the retained metal ions were eluted with $1.5 \mathrm{~mL}$ of 1.2 $\mathrm{mol} \mathrm{L}^{-1} \mathrm{HNO}_{3}$ for their future analysis (off-line). The analytes in the effluents were determined by ICPMS. The column could be used repeatedly after regeneration with $1.2 \mathrm{~mol} \mathrm{~L}^{-1} \mathrm{HNO}_{3}$ and deionized water. The recoveries of the analytes were calculated from the ratio of the concentration found by ICPMS to that of the initial sample.

\section{RESULTS AND DISCUSSION}

\section{Effect of $\mathrm{pH}$ on Adsorption}

In this work, the sample $\mathrm{pH}$ plays an important role in the adsorption of the analytes on CNFs loaded with HOx because of its effects on the formation of the metal-OHx chelating compound and the surface speciation of the adsorbent. For this reason, the effect of $\mathrm{pH}$ on the adsorption of the analytes on CNFs-OHx was investigated under dynamic conditions. The sample solutions were adjusted to the $\mathrm{pH}$ range of 1.0-9.0 with $\mathrm{HNO}_{3}$ and $\mathrm{NH}_{3} \cdot \mathrm{H}_{2} \mathrm{O}$ and then passed through the microcolumn. The effects of $\mathrm{pH}$ on the recoveries of the analytes are shown in Figure 1. As can be seen, the quantitative

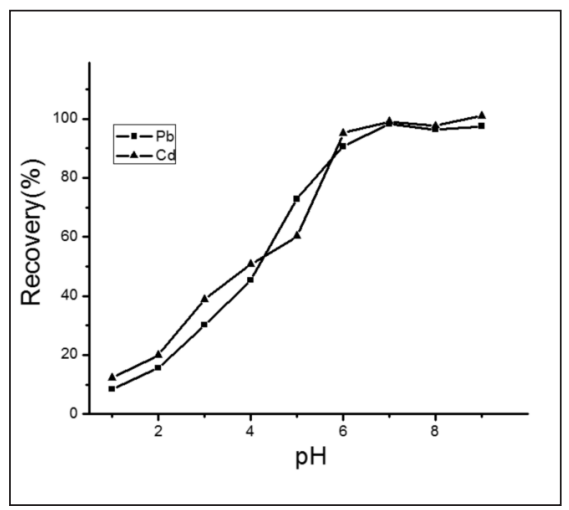

Fig. 1. Effect of $p H$ on the adsorption of analytes on CNFs-HOx. $\mathrm{Pb}^{2+}$ and $C d^{2}: 1.0 \mathrm{ng} \mathrm{mL}^{-1}$; sample volume : $20 \mathrm{~mL}$. recoveries of the analytes (>90\%) were found in the $\mathrm{pH}$ range from 6.0 to 9.0. Thus, a $\mathrm{pH}$ of 8.0 was used in the following experiments.

\section{Selection of Elution Parameters}

It can be seen from Figure 1 that the adsorption percentages of the analytes on the CNFs-OHx decreased significantly at $\mathrm{pH}<1.0$. Thus, various concentrations of $\mathrm{HNO}_{3}$ were studied for desorption of the retained analytes from the microcolumn. The results in Table II show that $1.2 \mathrm{~mol} \mathrm{~L}^{-1} \mathrm{HNO}_{3}$ was sufficient for the quantitative elution of the analytes (>90\%). Furthermore, the effect of eluent flow rate on the recovery of the analytes was examined by maintaining $1.5-\mathrm{mL}$ eluent volume and a concentration of $1.2 \mathrm{~mol} \mathrm{~L}^{-1}$ eluent, respectively. The experimental results indicated that any flow rate

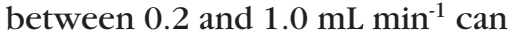
be used for the quantitative elution of the analytes. To obtain as short an analysis time as possible, the flow rate of the eluent was set at $0.9 \mathrm{~mL} \mathrm{~min}^{-1}$ in this work.

In addition, the effect of eluent volume on the recoveries of the analytes was also studied with $\mathbf{1 . 2}$ mol L-1 $\mathrm{HNO}_{3}$ solution. The results in Table III show that quantitative recoveries $(>90.0 \%$ ) could be obtained with $1.5 \mathrm{~mL}$ of $1.2 \mathrm{~mol} \mathrm{~L}^{-1}$ $\mathrm{HNO}_{3}$ solution. In this work, 1.5 $\mathrm{mL}$ of $1.2 \mathrm{~mol} \mathrm{~L}^{-1} \mathrm{HNO}_{3}$ solution

TABLE II

Effect of Eluent Concentration on the Recovery of Analytes

\begin{tabular}{ccc}
\hline $\begin{array}{c}\text { Conc. } \\
\left(\mathrm{HNO}_{3},\right.\end{array}$ & \multicolumn{2}{c}{ Recovery (\%) } \\
$\left.\mathrm{mol} \mathrm{mL}^{-1}\right)$ & $\mathrm{Pb}^{2+}$ & $\mathrm{Cd}^{2+}$ \\
\hline 0.2 & 34.7 & 41.3 \\
0.5 & 60.1 & 56.8 \\
0.8 & 88.4 & 85.2 \\
1.2 & 96.3 & 98.3 \\
1.5 & 97.4 & 96.7 \\
2.0 & 98.9 & 99.1 \\
\hline
\end{tabular}

was used for the quantitative elution of the analytes.

\section{Effect of Sample Solution Flow Rate}

The flow rate of the sample solution is an important factor for the quantitative extraction of analytes since it controls the analysis time and affects the retention of the analytes on the microcolumn. Therefore, the flow rate of the sample solution was optimized in the range of 0.2 to $2.5 \mathrm{~mL} \mathrm{~min}^{-1}$. The results in Figure 2 indicate that at a flow rate higher than $1.5 \mathrm{~mL} \mathrm{~min}^{-1}$, there was a decrease in the recoveries of the studied ions. The reason for this is insufficient contact between the analytes and the adsorbent to reach equilibrium. Therefore, all subsequent experiments were performed at a flow rate of $1.4 \mathrm{~mL} \mathrm{~min}{ }^{-1}$ (offline for ICP-MS).

\section{Effect of Sample Solution Volume}

In order to explore the possibility of enriching low concentrations of analytes from a large sample volume, the effect of sample volume on the adsorption of the analytes was studied. For this purpose, 25 , 50, 100, 150, 200, 250, and $300 \mathrm{~mL}$ of the sample solutions containing $15 \mathrm{ng}$ of the analytes were passed through the microcolumn at a 1.4 $\mathrm{mL} \mathrm{min}^{-1}$ flow rate. The results from Figure 3 show that quantitative recoveries (>90\%) were obtained for sample volumes up to $150 \mathrm{~mL}$.

TABLE III

Effect of Eluent Volume on the Recovery of Analytes

\begin{tabular}{ccc}
\hline $\begin{array}{c}\text { Eluent } \\
\text { Volume } \\
\left(\mathrm{HNO}_{3}, \mathrm{~mL}\right)\end{array}$ & \multicolumn{2}{c}{ Recovery (\%) } \\
\hline 0.5 & 41.2 & 38.4 \\
1.0 & 56.7 & 60.1 \\
1.5 & 93.8 & 94.5 \\
2.0 & 96.4 & 95.8 \\
3.0 & 97.5 & 98.3 \\
\hline
\end{tabular}




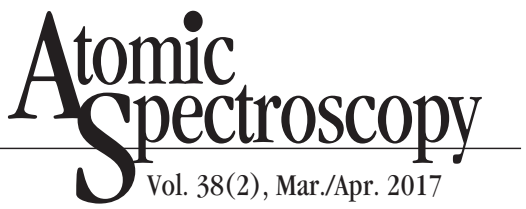

Because the elution volume was $1.5 \mathrm{~mL}$, a 100-fold enrichment factor was obtained for the studied ions. Considering the analysis time, a 20 -mL sample volume was used for the analysis of real samples in this study.

\section{Adsorption Capacity}

The adsorption capacity study was based on the method recommended in the literature (41). To achieve this purpose, $20-\mathrm{mL}$ aliquots of the sample solutions containing a series of concentrations of analytes were adjusted to the desired $\mathrm{pH}$, and then preconcentrated and eluted according to this procedure. The quantity of the analytes adsorbed at each concentration level was determined by ICP-MS. The adsorption isotherm curve of the analytes was obtained by plotting the concentrations of the analytes versus the milligrams of the analytes adsorbed on per gram of adsorbent. The adsorption capacity of CNFs-OHx calculated from the adsorption isotherm curve was $4.3 \mathrm{mg} \mathrm{g}^{-1}$ and $5.0 \mathrm{mg} \mathrm{g}^{-1}$ for $\mathrm{Pb}$ and $\mathrm{Cd}$, respectively.

\section{Effect of Interfering Ions}

The effects of potential interfering cations and anions in environmental and biological samples on the preconcentration, separation, and determination of the analytes were examined under the optimum conditions. The tolerance limit of interfering ions is defined as the largest amount making the recovery of the analyte less than $90 \%$. The different concentrations of the interfering ions were individually added to the solution containing $1.0 \mathrm{ng} \mathrm{mL}^{-1}$ of the analytes, and their effects on the recoveries of the analytes were investigated. It can be seen from Table IV that the major cations and anions were not found to interfere with the adsorption and determination of the analytes in the range of their amounts tested.

\section{Column Reuse}

The stability and potential regeneration of the microcolumn were assessed by monitoring the change in the recoveries of the analytes. The column can be reused after regeneration with $10 \mathrm{~mL}$ of 1.2 mol L-1 $\mathrm{HNO}_{3}$ solution and $20 \mathrm{~mL}$ deionized water, respectively, and is stable up to 50 adsorption-elution cycles without obvious decrease in the recoveries of the analytes.

\section{Analytical Performance}

The analytical performance of this method, including precision, linear range of calibration curve, and detection limits, was carried out under the optimum experimental conditions. The detection limits
TABLE IV Effect of Coexisting Ions

\begin{tabular}{lc}
\hline $\begin{array}{c}\text { Coexisting } \\
\text { Ions }\end{array}$ & $\begin{array}{c}\text { Concentration } \\
\text { Ratio }\end{array}$ \\
\hline $\mathrm{Na}^{+}, \mathrm{K}^{+}$ & 50,000 \\
$\mathrm{Ca}^{2+}, \mathrm{Mg}^{2+}$ & 20,000 \\
$\mathrm{Al}^{3+}, \mathrm{Fe}^{3+}$ & 200 \\
$\mathrm{SiO}_{3}{ }^{2-}, \mathrm{SO}_{4}{ }^{2-}, \mathrm{PO}_{4}{ }^{3-}$ & 2000 \\
\hline
\end{tabular}

${ }^{a}$ Concentration ratio: Foreign ion/determined ions.

of $\mathrm{Pb}$ and $\mathrm{Cd}$, based on three times the standard deviation of the blank solution, were 3.0 and $0.7 \mathrm{pg} \mathrm{mL}^{-1}$, respectively, with a 100 -fold enrichment factor. The linear range of this method was from 0.1 to $100 \mathrm{ng} \mathrm{mL}^{-1}$ with the correlation coefficient better than 0.9987 . The precision for the nine determinations of $1.0 \mathrm{ng}$ $\mathrm{mL}^{-1}$ of $\mathrm{Pb}$ and $\mathrm{Cd}$ were $3.9 \%$ and $4.8 \%$, respectively.

\section{Validation and Application}

In order to identify the accuracy of this procedure, a natural water sample and a certified reference material of mussel (GBW 08571) (obtained from the Institute of Geophysical and Gechemical prospecting, Langfang, P.R. China) were analyzed under the selected conditions. The obtained results are summarized in Table V and VI, respectively. As can be seen, the

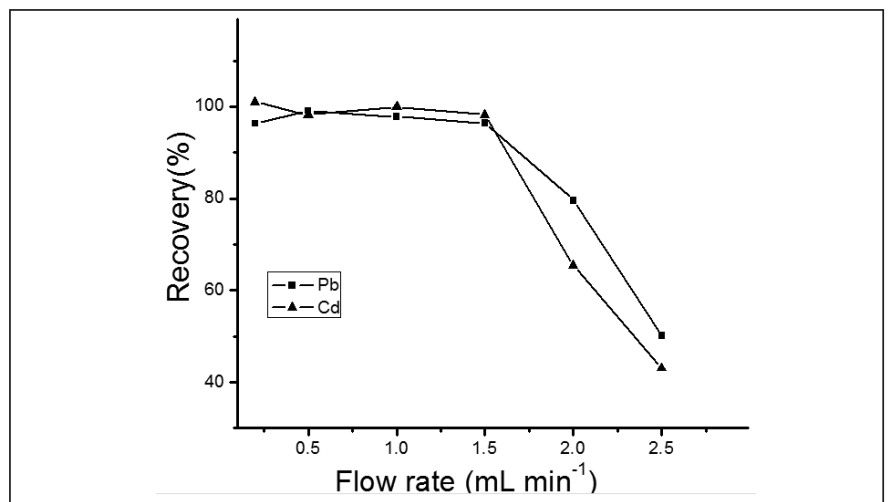

Fig. 2. Effect of sample flow rate on the recovery of analytes on CNFs-HOx. $\mathrm{Pb}^{2+}$ and $\mathrm{Cd}^{2+}: 1.0 \mathrm{ng} \mathrm{mL}^{-1} ; \mathrm{pH}=8.0$; sample volume : $20 \mathrm{~mL}$.

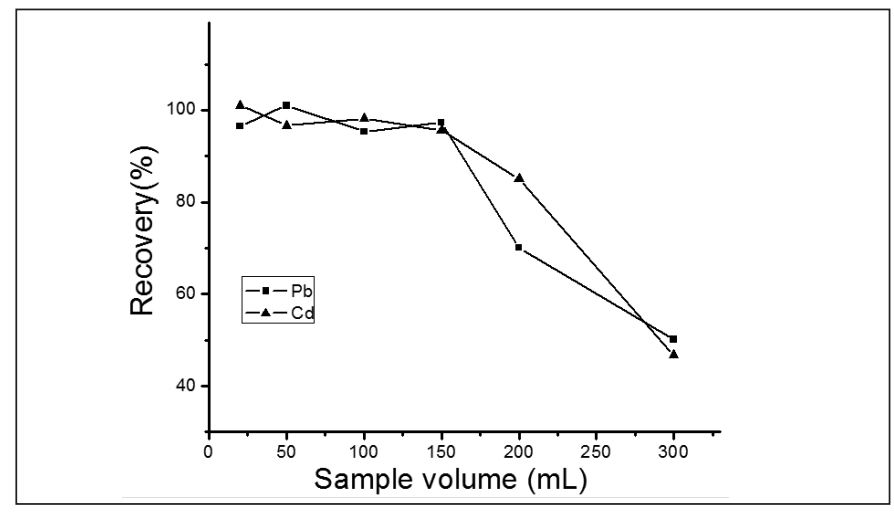

Fig. 3. Effect of sample volume on the recovery of analytes on CNFs-HOx. $\mathrm{pH}$ : 8.0; sample volume : $20 \mathrm{~mL} ; \mathrm{Pb}^{2+}$ and $C d^{2+}: 15 n g$. 
TABLE V

Analytical Results of Analytes in Natural Water Samples

\begin{tabular}{cccc}
\hline Element & $\begin{array}{c}\text { Added } \\
\left(\mathrm{ng} \mathrm{mL}^{-1}\right)\end{array}$ & $\begin{array}{c}\text { Found }^{\mathrm{a}} \\
\left(\mathrm{ng} \mathrm{mL}^{-1}\right)\end{array}$ & $\begin{array}{c}\text { Recovery } \\
(\%)\end{array}$ \\
\hline $\mathrm{Pb}$ & 0 & $1.23 \pm 0.08$ & - \\
& 2.0 & $3.16 \pm 0.17$ & 96.5 \\
$\mathrm{Cd}$ & 5.0 & $6.38 \pm 0.34$ & 103 \\
& 0 & $0.46 \pm 0.03$ & - \\
& 1.0 & $1.41 \pm 0.10$ & 95.0 \\
& 2.0 & $2.48 \pm 0.15$ & 101 \\
\hline
\end{tabular}

${ }^{a}$ Mean value \pm standard deviation, $n=3$.
TABLE VI Analytical Results of Analytes in Certified Reference Material of Mussel

\begin{tabular}{ccccc}
\hline Element & $\begin{array}{c}\text { Added } \\
\left(\mu \mathrm{g} \mathrm{g}^{-1}\right)\end{array}$ & $\begin{array}{c}\text { Found }^{\mathrm{a}} \\
\left(\mu \mathrm{g} \mathrm{g}^{-1}\right)\end{array}$ & $\begin{array}{c}\text { Certified } \\
\left(\mu \mathrm{g} \mathrm{g}^{-1}\right)\end{array}$ & $\begin{array}{c}\text { Recovery } \\
(\%)\end{array}$ \\
\hline $\mathrm{Pb}$ & 0 & $2.24 \pm 0.15$ & $1.96 \pm 0.09$ & - \\
& 2.0 & $4.26 \pm 0.28$ & - & 101 \\
$\mathrm{Cd}$ & 0 & $5.10 \pm 0.30$ & $4.5 \pm 0.5$ & - \\
& 2.0 & $7.05 \pm 0.53$ & - & 97.5 \\
\hline \multicolumn{4}{c}{ Mean value + standard deviation $n=3}$.
\end{tabular}

${ }^{a}$ Mean value \pm standard deviation, $n=3$. determined values were in good agreement with the certified values, and the recoveries of the analytes were in the range of $95-103 \%$.

\section{CONCLUSION}

Based on the use of carbon nanofibers (CNFs) loaded with 8-Hydroxyquinoline ( $\mathrm{HOx}$ ) as a solid phase extraction adsorbent packed in a microcolumn, an effective preconcentration and separation procedure was developed for the determination of trace $\mathrm{Pb}$ and $\mathrm{Cd}$ in biological and environmental samples by inductively coupled plasma mass spectrometry (ICPMS). The adsorption behavior of the analytes on CNFs-OHx was investigated systematically. The analytes were retained on $\mathrm{CNFx}$-OHx in the $\mathrm{pH}$ range of 6.0-9.0 and desorbed quantitatively with 1.5 $\mathrm{mL}$ of $1.2 \mathrm{~mol} \mathrm{~L}^{-1} \mathrm{HNO}_{3}$ solution. In addition, no carryover was observed in the next analysis. An enrichment factor of 100 -fold was achieved. The adsorption capacity of CNFs-HOx for $\mathrm{Pb}$ and $\mathrm{Cd}$ was 4.3 $\mathrm{mg} \mathrm{g}^{-1}$ and $5.0 \mathrm{mg} \mathrm{g}^{-1}$, respectively. It may be expected that the incorporation of complexing reagents in nanometer solid supports is likely to become an important strategy for trace/ultra-trace elements and their speciation in real samples.

\section{ACKNOWLEDGMENT}

The authors are grateful for the financial support of Special Fund for Agroscientific Researching in the Public Interest (Project No. 201503135-22).

Received November 4, 2016.

\section{REFERENCES}

1. M. Tuzen, S. Sahiner, and B. Hazer, Food Chem. 210, 115 (2016).

2. Y. He, S. Chen, X. Zhou, and X. Wang, At. Spectrosc. 33(4), 117 (2012).

3. M. Behbahani, P.G. Hassanlou, M. M. Amini, F. Omidi, A. Esrafili, M. Farzadkia, and A. Bagheri, Food Chem. 187, 82 (2016).

4. A.C.M. Aleluia, F.A. de Santana, G.C. Brandao, and S.L.C. Ferreira, Microchem. J. 130, 157 (2017).

5. P. Liang, C. Kang, and L. Wen, At. Spectrosc. 37(1), 30 (2016).

6. 4. A.A. Alqadami, M.A. Abdalla, Z.A. Alothman, and K. Omer, Int. J. Environ Res. Public Health 10, 361 (2013).

7. D. Ozdes and C. Duran, At. Spectrosc. 35(3), 118 (2014).

8. T. Bora, C. Aksoy, Z. Tunay, and F. Aydın, Microchem. J. 123, 179 (2015).

9. C. Tai, S. Jiang, and A.C. Sahayam,
Food Chem.192, 274 (2016).

10. Y. Zhang, X. Mao, J. Liu, M. Wang, Y. Qian, C. Gao, and Y. Qi, Spectrochim. Acta Part B 118, 119 (2016).

11. T. Shih, C. Hsieh, Y. Luo, Y. Su, P. Chen, Y. Chuang, and Y. Sun, Anal. Chim. Acta 916, 24 (2016).

12. Y. Fang, Y. Pan, P. Li, M. Xue, F. Pei, W. Yang, N. Ma, and Q. Hu, Food Chem. 213, 609 (2016).

13. D. Rahmi, Y. Takasaki, Y. Zhu, H. Kobayashi, S. Konagaya, H. Haraguchi, and T. Umemur, Talanta 81(4-5), 1438 (2010).

14. B.K. Nagar, S.B. Deb, M.K. Saxena, and K.L. Ramakumar, At. Spectrosc. 32(6), 213 (2011).

15. J. Li, L. Zhong, X. Tu, X. Liang, and J. Xu, Talanta 81(3), 954 (2010).

16. S. Serife and K. Senol, Microchim. Acta 170(1-2), 75 (2010).

17. S. Mustafa and Y. Sevtap, At. Spectrosc. 36(4), 165 (2015).

18. S. Chen, S. Zhu, Y. He, and D. Lu, Food Chem. 150, 254 (2014).

19. R. Habib, M.S. Javad, and M. Rahim, Microchim. Acta 183(2), 555 (2016).

20. S. Chen, S. Zhu, and D. Lu, Food Chem. 169, 156 (2015).

21. M. Soylak and M. Karaca, At. Spectrosc. 37(3), 108 (2016).

22. H. Knutson, M.M. Hansen, C. Jönsson, N. Borg, and B. Nilsson, J. Chromatogr. A 1348, 47 (2014). 


\section{A Spectroscopy $_{\text {pec }}^{\text {tom }}$ \\ 1 Vol. 38(2), Mar./Apr. 2017}

23. R. Koplík, M. Borková, B. Bicanová, J. Polák, O. Mestek, and J. Komínková, Food Chem. 99, 158 (2006).

24. M.A. Habila, Z.A. Alothman, and M. Soylak, At. Spectrosc. 36(3), 146 (2015).

25. G. H. Liu, Y. F. Zhu, X. R. Zhang, and B. Q. Xu, Anal. Chem. 74(24), 6279 (2002)

26. W. Hong, W. Hongyu, H. Baoping, D. Baixiang, L. Jusheng, and T. Jiuying, Microchim. Acta 166(1-2), 41(2009)

27. A.A. Gouda and S.M.A. Ghannam, Food Chem. 202, 409 (2016).

28. R. Yinzhe, F. Zhefeng, and W. Jianying, Microchim. Acta 158(3-4), 227 (2007).

29. W. Tian and Z. Fan, At. Spectrosc. 33(1), 1 (2012).

30. M. Behbahani, A. Bagheri, M. Taghizadeh, M. Salarian, O. Sadeghi, L. Adlnasab, and K. Jalali, Food Chem. 138(2-3), 2050 (2013).

31. A. Chambers, C. Park, R. T. K. Baker, and N. M. Rodriguez, J. Chem. Phys. B 102(22), 4253 (1998).

32. Y. He, S. Chen, X. Zhou, and X. Wang, At. Spectrosc. 33(4), 117 (2012).

33. S. Chen, M. Xiao, D. Lu, and X Zhan, Rapid Comm. Mass Spectrom. 21, 2524 (2007).

34. S. Chen, X. Zhan, D. Lu, and C. Liu, At. Spectrosc. 29(4), 124 (2008).

35. M. Tuzen, K.O. Saygi, and M. Soylake, J. Hazard. Mater. 632, 152 (2008).

36. E.M. Soliman, M.B. Saleh, and S.A. Ahmed, Anal. Chim. Acta 523, 133 (2004).

37. S. Chen, Y. He, Y. Zhang, and D. Lu, At. Spectrosc. 36(4), 153 (2015).

38. M. Ghaedi, A. Shokrollahi, A.H. Kianfar, A. Pourfarokhi, N. Khanjari, A.S. Mirsadeghi, and M. Soylak, J. Hazard. Mater. 162, 1408 (2009).

39. G. Kaya, I. Akdeniz, and M. Yaman, At. Spectrosc. 29(4), 150 (2009).

40. P. V. Lakshiminarayanan, H. Toghiani, and C. U. Pittman Jr, Carbon 42, 2433 (2004)
41. A. Maqieira, H.AM. Elmahadi, and R. Puchades, Anal. Chem. 66, 3632 (1994). 